\title{
Erythrocyte transketolase activity in suspected cases of Leigh's disease, or subacute necrotising encephalomyelopathy
}

\author{
A MCBURNEY, DENIS LEIGH, AND H MCILWAIN \\ Department of Biochemistry, Institute of Psychiatry, and Maudsley Hospital, London
}

SUMMARY Erythrocyte transketolase activity and the effect of adding thiamine pyrophosphate ( $\%$ thiamine pyrophosphate effect) were measured in 111 subjects suspected to suffer from Leigh's disease (subacute necrotising encephalomyelopathy). From clinical evidence these subjects were divided into five groups: (1) necropsy-proved cases of subacute necrotising encephalomyelopathy, (2) cases positive for urinary thiamine pyrophosphate: adenosine triphosphate phosphotransferase inhibitor, (3) clinically likely cases of subacute necrotising encephalomyelopathy (patients still alive, or on whom no necropsy was performed), (4) cases diagnosed as diseases other than subacute necrotising encephalomyelopathy (control group), (5) cases for which no diagnosis had been made.

Comparison of erythrocyte transketolase activities with and without added thiamine pyrophosphate and of the \% thiamine pyrophosphate effect for each group compared with the control group showed no statistically significant differences from normal values for any of these parameters. Similarly, there were no differences between the two sexes in transketolase activity, and no correlation between transketolase activity and age. These results indicate that erythrocyte transketolase activity is not altered in subacute necrotising encephalomyelopathy and is unlikely to be of value for the diagnosis of Leigh's disease.

The symptoms and clinical and pathological findings in subacute necrotising encephalomyelopathy (SNE) or Leigh's disease were reviewed by Monpetit et al. ${ }^{1}$ and Pincus. ${ }^{2}$ The recessive mode of inheritance and the various biochemical abnormalities that have been detected suggest that the condition is the result of an inborn error of metabolism. ${ }^{3}$

Although it generally presents before age 2 years in children who had previously been healthy, SNE can first manifest itself in adolescence or early adulthood. Clinically it is difficult to diagnose, but psychomotor retardation, the presence of cranial nerve lesions and respiratory disorders in the hypotonic child, with exacerbation and remission of the symptoms and signs may suggest the diagnosis. The difficulty in clinical diagnosis leads to uncertainty in evaluating the results of any biochemical investigations except in cases in which the diagnosis has been confirmed at necropsy, or in cases where a sibling has died with SNE proved at necropsy. However, the discovery by Cooper et al. ${ }^{4}$ of a substance present in the body fluids of patients with SNE which inhibits the formation of thiamine triphosphate by the enzyme thiamine pyrophosphate (TPP): adenosine triphosphate (ATP) phosphotransferase, led to an assay for this inhibitor substance in the urine of patients suspected of having SNE. The specificity of the assay was discussed by Pincus et al. $;^{5}$ their data suggested that the inhibitor was linked with the presence of the disease in sick children. However, others, with the exception of Murphy et al., ${ }^{6}$ have been unable to operate the assay successfully, and at present there are some doubts about it.

The inhibitor substance disappears from the urine if the patient is receiving thiamine; ${ }^{7}$ referring physicians are not always aware of this fact, and a negative finding will result if the sample is not satisfactory. Nevertheless, at the present time, the presence of this inhibitor substance in samples of urine is a potentially valuable guide for the diagnosis of SNE in children presenting with symptoms and signs of this disease.

The brain lesions which occur in SNE are very 
similar to those found in the Wernicke-Korsakoff syndrome, except that in SNE the mamillary bodies are not generally affected. As the WernickeKorsakoff syndrome has been shown to involve a defect in thiamine metabolism, it has been suggested that SNE may also reflect a disturbance in thiamine metabolism. ${ }^{4}$ 8-9 To date however, the manner in which thiamine is associated with the formation of brain lesions in SNE is not understood. In a few cases, the activities of enzymes requiring TPP as cofactor have been investigated but have produced equivocal results. ${ }^{310-15}$

As there have been no extensive studies of the involvement of TPP-dependent erthyrocyte transketolase in cases of SNE it was decided to investigate activity of this enzyme in suspected cases of Leigh's disease.

\section{Patients}

Samples were obtained from 111 children in whom the diagnosis of SNE had been suspected. Samples were received from hospitals in the UK and West Germany. Clinical records were studied and a follow up made, as far as was possible, into the course of the illness.

Particular attention was given to the diagnostic opinion of the referring physician, and on this basis the subjects were divided into five groups: (1) necropsy-proved cases of SNE $(n=4)$, (2) cases positive for urinary TPP:ATP phosphotransferase inhibitor $(n=17),(3)$ clinically possible cases of SNE (cases still alive, or on whom no necropsy was performed) $(n=21)$, (4) cases diagnosed as diseases other than SNE (control group) $(n=36),(5)$ cases for which no diagnosis had been made $(\mathrm{n}=33)$.

\section{Materials and methods}

Dithiothreitol (DTT); nicotinamide adenine dinucleotide, reduced (NADH); thiamine pyrophosphoric acid chloride; and glycerol-3-phosphate: NAD 2-oxidoreductase (D-glyceraldehyde-3phosphate ketol isomerase, EC 1.1.18/EC 5.3.1.1. or GDH/TIM) were obtained from Boehringer Mannheim. D-Ribose-5-phosphate (disodium salt) and tris (hydroxymethyl) aminomethane were from Sigma London Ltd; magnesium chloride was supplied by BDH, Poole, Dorset.

Venous blood was collected in tubes containing lithium heparin, centrifuged at $0^{\circ} \mathrm{C}$ and $3000 \mathrm{rev} / \mathrm{min}$ for $15 \mathrm{~min}$, and plasma and buffy coat removed. The erythrocytes were then either frozen at $-20^{\circ} \mathrm{C}$ and stored, or were prepared immediately for assay as follows: $0.5 \mathrm{ml}$ erythrocytes were diluted with $2 \mathrm{ml}$ distilled water and haemolysed by rapid freezing and thawing (three times) in dry ice/methanol. Stroma were removed by centrifugation at $0^{\circ} \mathrm{C}$ and 3000 $\mathrm{rev} / \mathrm{min}$ for $15 \mathrm{~min}$ and the supernatant used for assay of transketolase (D-sedoheptulose-7-phosphate: D-glyceraldehyde-3-phosphate glycoaldehyde transferase, EC 2.2.11 or TK).

The method used for determination of transketolase activity was essentially that of Vo-Khactu et al. ${ }^{16}$ The only differences were as follows: $50 \mu \mathrm{l}$ haemolysate were assayed using $100 \mathrm{mmol} / 1$ tris$\mathrm{HCl}$ buffer $\mathrm{pH} 7 \cdot 6$ containing $1 \mathrm{mmol} / 1 \mathrm{DTT}$ and $5 \mathrm{mmol} / 1 \mathrm{MgCl}_{2}$; reference cuvettes contained $2.7 \mathrm{ml}$ buffer and $50 \mu l$ haemolysate; readings at $340 \mathrm{~nm}$ were taken at 30 -second intervals for $15 \mathrm{~min}$.

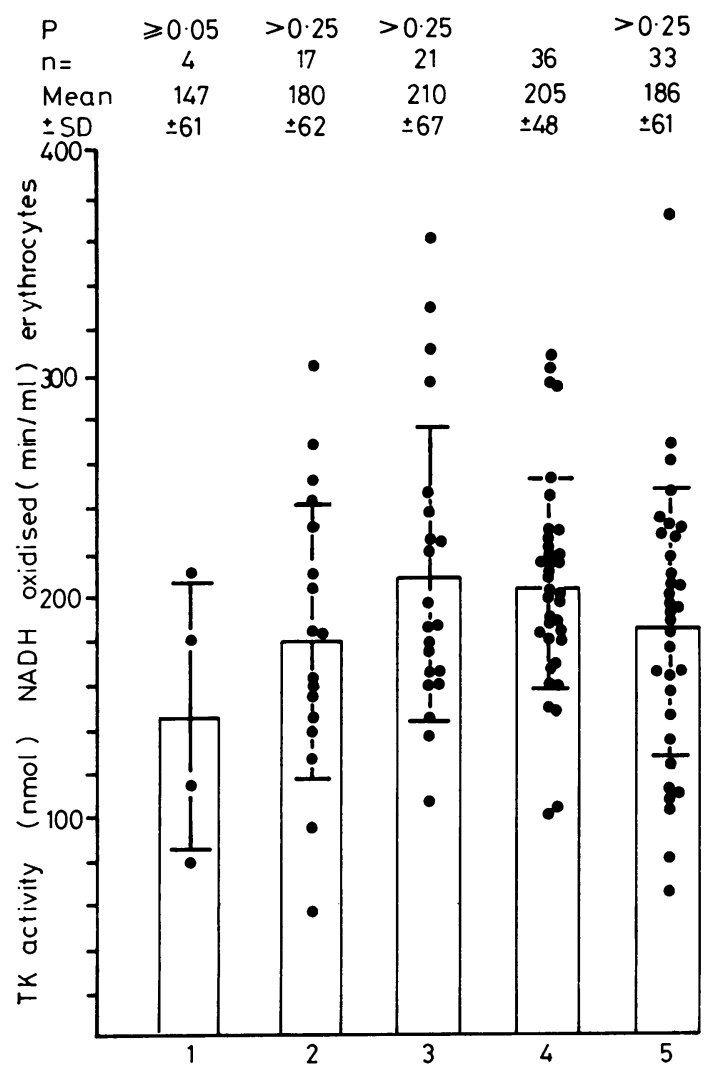

Fig. 1 Transketolase activity in erythrocyte haemolysates from: (1) necropsy-proved cases of $S N E$, (2) TPP : ATP phosphotransferase inhibitor positive cases, (3) clinically possible cases of $S N E$, (4) cases diagnosed as other than $S N E$, (5) as yet undiagnosed cases.

The mean \pm 1 standard deviation in each group is shown in addition to the individual values. The $P$ values denote the statistical significance, by the Student's $t$ test, for differences between the control group (group 4) and the others. 
Activity was expressed as nmol NADH oxidised/ $\mathrm{min} / \mathrm{ml}$ erythrocytes. Transketolase activity was determined in duplicate in the presence and absence of exogenous TPP and the stimulatory effect expressed as follows:

$\%$ TPP effect $=100 \times[$ (TK activity with TPP $)-$ (TK activity without TPP)]/(TK activity with TPP).

Urine, minimum volume $5 \mathrm{ml}$, was dried on filter paper (Whatman $3 \mathrm{MM}, 10 \times 8 \mathrm{~cm}$ ) as described by Cooper ${ }^{5}$ and despatched to Yale University for determination of TPP:ATP phosphotransferase inhibition by the method previously described. ${ }^{5}$ Inhibition in excess of $40 \%$ was regarded as a positive result for the inhibitor substance.

\section{Results}

The reproducibility of the transketolase assay was determined by assaying one erythrocyte sample 10 times in the presence and absence of TPP. This resulted in coefficients of variation from the means, of 6.5 and $6.4 \%$ respectively. For the \% TPP effect, the mean value was $15 \cdot 5 \pm 8 \cdot 2$ and its coefficient of variation was $52.9 \%$. This figure compares favourably with other reported values for small increments (see Discussion).

The results of erythrocyte transketolase determinations are shown for all groups of subjects in Fig. 1. Each group was compared with the control group (group 4) and there were no significant differences.

Transketolase activities after adding the TPP are presented in Fig. 2. All groups showed increased activity and the relationships were the same as before the TPP was added. Similarly, no significant differences in the \% TPP effect were observed between the groups (Fig. 3). There was no correlation between age or sex and erythrocyte transketolase activity.

For 10 subjects blood and urine samples were

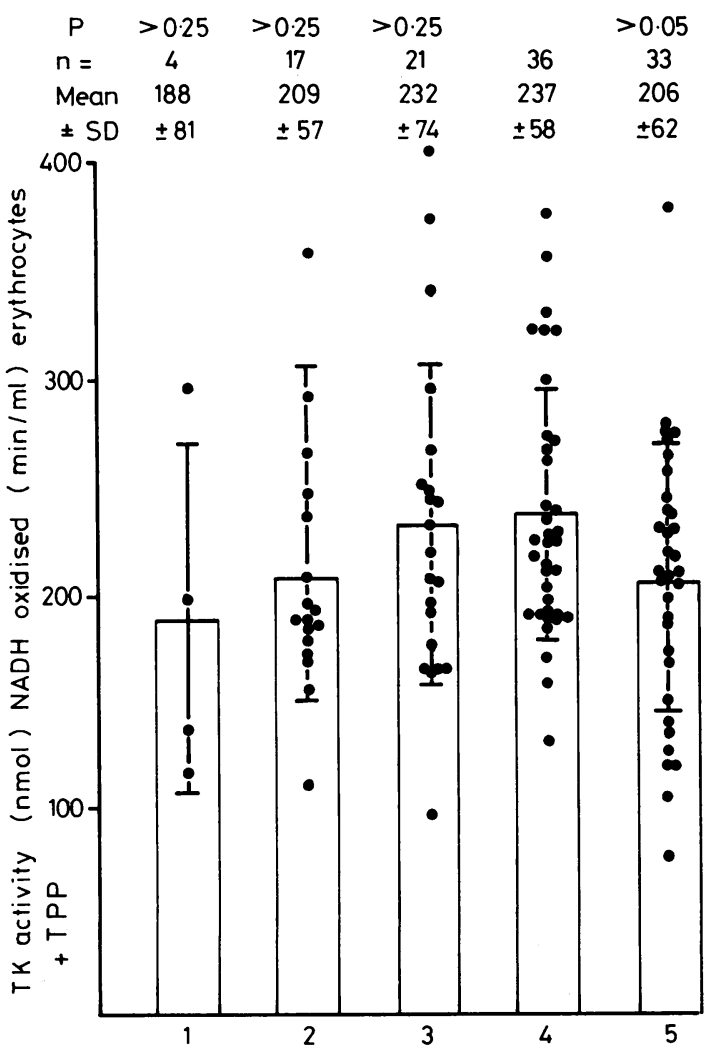

Fig. 2 Transketolase activity in erythrocyte haemolysates when thiamine pyrophosphate, final concentration $0.36 \mathrm{mmol} / \mathrm{l}$ was added before incubation, Other details are as in Fig. 1. 
Table Family studies of urinary inhibitor and erythrocyte transketolase activities

\begin{tabular}{|c|c|c|c|c|c|}
\hline \multirow[t]{2}{*}{ Case } & \multirow[t]{2}{*}{ Group } & \multirow[t]{2}{*}{ Inhibitor } & \multicolumn{2}{|c|}{$T K$ activity } & \multirow[t]{2}{*}{$\% T P P$ effect } \\
\hline & & & $-T P P$ & $+T P P$ & \\
\hline $\begin{array}{l}1 \\
\text { Brother } \\
\text { Mother } \\
\text { Father }\end{array}$ & 1 & $\begin{array}{l}\text { Negative } \\
\text { Positive } \\
\text { Negative } \\
\text { Positive }\end{array}$ & $\begin{array}{l}214 \\
261 \\
175 \\
110\end{array}$ & $\begin{array}{l}298 \\
310 \\
267 \\
118\end{array}$ & $\begin{array}{r}39.6 \\
18 \cdot 8 \\
52.6 \\
7 \cdot 3\end{array}$ \\
\hline $\begin{array}{l}2 \\
\text { Sister } \\
\text { Mother } \\
\text { Father }\end{array}$ & 1 & $\begin{array}{l}\text { Positive } \\
\text { Positive } \\
\text { Negative } \\
\text { Positive }\end{array}$ & $\begin{array}{l}\text { Not assa } \\
233 \\
204 \\
202\end{array}$ & $\begin{array}{r}\text { ayed } \\
224 \\
235 \\
211\end{array}$ & $\begin{array}{c}6 \\
15 \cdot 2 \\
4 \cdot 5\end{array}$ \\
\hline $\begin{array}{l}3 \\
\text { Sister } \\
\text { Mother } \\
\text { Father }\end{array}$ & 2 & $\begin{array}{l}\text { Positive } \\
\text { Negative } \\
\text { Negative } \\
\text { Negative }\end{array}$ & $\begin{array}{l}140 \\
181 \\
141 \\
139\end{array}$ & $\begin{array}{l}197 \\
219 \\
170 \\
159\end{array}$ & $\begin{array}{l}40 \cdot 7 \\
20 \cdot 9 \\
20 \cdot 6 \\
14 \cdot 4\end{array}$ \\
\hline $\begin{array}{l}4 \\
\text { Mother } \\
\text { Father }\end{array}$ & 2 & $\begin{array}{l}\text { Positive } \\
\text { Negative } \\
\text { Negative }\end{array}$ & $\begin{array}{l}268 \\
157 \\
195\end{array}$ & $\begin{array}{l}294 \\
162 \\
230\end{array}$ & $\begin{array}{r}9 \cdot 7 \\
3 \cdot 2 \\
17 \cdot 9\end{array}$ \\
\hline $\begin{array}{l}5 \\
\text { Mother } \\
\text { Father }\end{array}$ & 2 & $\begin{array}{l}\text { Positive } \\
\text { Negative } \\
\text { Negative }\end{array}$ & $\begin{array}{l}189 \\
215 \\
207\end{array}$ & $\begin{array}{l}195 \\
235 \\
217\end{array}$ & $\begin{array}{l}3 \cdot 2 \\
9 \cdot 3 \\
4 \cdot 8\end{array}$ \\
\hline $\begin{array}{l}6 \\
7 \\
\text { Brother } \\
\text { Motber } \\
\text { Father }\end{array}$ & $\begin{array}{l}2 \\
2\end{array}$ & $\begin{array}{l}\text { Positive } \\
\text { Positive } \\
\text { Not assayed } \\
\text { Not assayed } \\
\text { Not assayed }\end{array}$ & $\begin{array}{l}184 \\
232 \\
229 \\
100 \\
205\end{array}$ & $\begin{array}{l}192 \\
247 \\
255 \\
121 \\
240\end{array}$ & $\begin{array}{r}4 \cdot 3 \\
6 \cdot 5 \\
11 \cdot 4 \\
21 \cdot 0 \\
17 \cdot 1\end{array}$ \\
\hline $\begin{array}{l}\mathbf{8} \\
\text { Sister } \\
\text { Mother } \\
\text { Father }\end{array}$ & 3 & $\begin{array}{l}\text { Negative } \\
\text { Negative } \\
\text { Negative } \\
\text { Negative }\end{array}$ & $\begin{array}{l}138 \\
232 \\
206 \\
\text { Not assa }\end{array}$ & $\begin{array}{l}169 \\
281 \\
193 \\
\text { yed }\end{array}$ & $\begin{array}{c}22 \cdot 5 \\
21 \cdot 1 \\
0\end{array}$ \\
\hline $\begin{array}{l}9 \\
\text { Mother } \\
\text { Father }\end{array}$ & 3 & $\begin{array}{l}\text { Negative } \\
\text { Negative } \\
\text { Negative }\end{array}$ & $\begin{array}{l}165 \\
127 \\
164\end{array}$ & $\begin{array}{l}168 \\
204 \\
180\end{array}$ & $\begin{array}{r}1 \cdot 8 \\
60 \cdot 6 \\
9 \cdot 8\end{array}$ \\
\hline $\begin{array}{l}10 \\
11 \\
\text { Sister } \\
\text { Mother } \\
\text { Father }\end{array}$ & $\begin{array}{l}3 \\
3\end{array}$ & $\begin{array}{l}\text { Negative } \\
\text { Negative } \\
\text { Negative } \\
\text { Negative } \\
\text { Negative }\end{array}$ & $\begin{array}{l}182 \\
159 \\
179 \\
200 \\
150\end{array}$ & $\begin{array}{l}187 \\
181 \\
233 \\
216 \\
158\end{array}$ & $\begin{array}{r}2 \cdot 7 \\
13 \cdot 8 \\
30 \cdot 2 \\
8 \cdot 0 \\
5 \cdot 3\end{array}$ \\
\hline $\begin{array}{l}12 \\
\text { Mother } \\
\text { Father }\end{array}$ & 4 & $\begin{array}{l}\text { Negative } \\
\text { Negative } \\
\text { Negative }\end{array}$ & $\begin{array}{l}204 \\
180 \\
164\end{array}$ & $\begin{array}{l}226 \\
207 \\
210\end{array}$ & $\begin{array}{l}10 \cdot 8 \\
15 \cdot 0 \\
28 \cdot 0\end{array}$ \\
\hline
\end{tabular}

TK activity expressed as nmol NADH oxidised $\mathrm{min} / \mathrm{ml}$ packed erythrocytes.

obtained from siblings and parents also. The results of these studies are shown in the Table. In 2 patients with SNE confirmed at necropsy, clinically normal siblings and fathers were found to be positive for the inhibitor while the mothers were negative. In the remaining cases, the results were as expected in that clinically normal siblings and parents were negative for the inhibitor; there were no pronounced differences from the propositus in erythrocyte transketolase levels. In all subjects erythrocyte transketolase levels were within normal ranges.

\section{Discussion}

Erythrocyte transketolase activity has been used clinically to determine thiamine status and has been shown to be a specific and accurate reflection of thiamine sufficiency. ${ }^{17-18}$ Methods of measuring the enzyme activity include colorimetric determination of sedoheptulose production, and ultraviolet spectrophotometric determination of NADH oxidation. Both methods, so far, have been shown to give comparable results for normal subjects. However, the activities reported here are higher than previously obtained, perhaps because of minor improvements in the assay procedure.

The determination of transketolase activity in the presence and absence of TPP, and the \% TPP effect in particular, has been regarded as a sensitive index of thiamine deficiency and a \% TPP effect greater than $25 \%$ is generally regarded as indicative of a deficiency state. ${ }^{17-18}$ However, it has often been 
reported that a high TPP effect does not always correlate with clinical findings ${ }^{19-21}$ and this, together with the large variation usually found in TPP effect determinations (coefficient of variation from the mean $50-85 \%$ ), limits the clinical significance of this parameter. The values of the TPP effect quoted for our control group agree with results reported for healthy individuals.

Apart from a role in determining thiamine deficiency the activity of erythrocyte transketolase has been investigated in a number of disease states-such as alcoholism, cancer, uraemia, neurosis, diabetes mellitus, anaemia, polyneuritis, and malnourishment secondary to vascular disease of the brain. In these conditions, enzyme levels have been shown to be significantly altered only in alcoholics, neurosis, and pernicious anaemia. In alcoholics, low enzyme levels were thought to reflect poor thiamine status as alcohol has been shown to block intestinal absorption of thiamine. Patients with neurosis were concluded to be thiamine-deficient due to poor food intake.22 Patients with pernicious anaemia showed significantly increased tranketolase activity and this was believed to be due to a larger population of young blood cells. ${ }^{23}$

For the few cases of Leigh's disease, in which transketolase activity has been determined, the results so far have been equivocal. In one study ${ }^{10}$ no change in activity was observed; in another ${ }^{15}$ significantly reduced enzyme levels accompanied by a high TPP effect were observed.

In addition to erythrocyte transketolase, there is also evidence, in SNE, to implicate deficiencies in other enzymes which require thiamine pyrophosphate as cofactor-for example pyruvate decarboxylase ${ }^{1124}$ and pyruvate dehydrogenase. ${ }^{25-26}$ So far results of investigations of these enzymes have also proved equivocal.

This study has established that erythrocyte transketolase activity is not affected in necropsyproved cases of SNE, nor is it affected in clinically likely cases, or in patients shown to be positive for an inhibitor of TPP: ATP phosphotransferase. In addition, studies of unaffected siblings and parents showed no pronounced differences from the propositus in terms of erythrocyte transketolase activities.

Results for the urinary inhibitor assay in these cases bear on the question of how this assay is used as a diagnostic criterion for SNE. Samples from 3 of the 4 necropsy-proved cases of SNE were negative for the inhibitor. It was also observed that 2 clinically normal siblings and their fathers in 2 necropsyconfirmed cases of SNE gave positive inhibitor results. These findings appear inconsistent with those of Pincus et al..$^{5}$ in which the inhibitor was positive in all 10 necropsy-proved cases of SNE. The reason for this discrepancy is not known, but it may result from delays in assaying the urine.

At present it seems that there is no single laboratory procedure which will diagnose Leigh's disease before death and it is possible that the disease may be the result of more than one metabolic abnormality.

Current results suggest that involvement of thiamine pyrophosphate in Leigh's disease will be in a role other than that of coenzyme in erythrocyte transketolase or as precursor of thiamine triphosphate. Evidence has suggested an additional neural function of thiamine ${ }^{27-28}$ and studies have been reported on a possible function of thiamine in neuromuscular transmission. ${ }^{29}$ It remains to be seen whether or not this approach will be more fruitful in elucidating the role of thiamine in the pathogenesis of Leigh's disease.

We thank the physicians and staff of 24 hospitals in Britain and West Germany for their co-operation in this study, and the Research Fund, Bethlem Royal Hospital and Maudsley Hospital, for support.

\section{References}

1 Montpetit V J A, Andermann F, Carpenter S, Fawcett J S. Zborowska - Slius D, Giberson H R. Subacute necrotising encephalomyelopathy, a review and a study of two families. Brain 1971; 94: 1-30.

2 Pincus J H. Subacute necrotizing encephalomyelopathy (Leigh's disease). A consideration of clinical features and etiology. Dev Med Child Neurol 1972; 14: 87-101.

3 Blass J P, Cederbaum S D, Dunn H G. Letter: Biochemical abnormalitıes in Leigh's disease. Lancet 1976; i: 1237-8.

4 Cooper J R, Itokawa Y, Pincus J H. Thiamine triphosphate deficiency in subacute necrotizing encephalomyelopathy. Science $1969 ; 164$ : 74-5.

5 Pincus J H, Cooper J R, Piros K, Turner V. Specificity of the urine inhibitor test for Leigh's disease. Neurology (Minneap) 1974; 24: 885-90.

- Murphy J V, Craig L J, Glew R H. Leigh's disease: biochemical characteristics of the inhibitor. Arch Neurol 1974; 31 : 220-7.

7 Cooper J R, Pincus J H, Itokawa Y, Piros K. Experience with phosphoryl transferase inhibition in subacute necrotizing encephalomyelopathy. $N$ Engl J Med 1970; 283: 793-5.

8 Leigh A D. Subacute necrotizing encephalomyelopathy in an infant. J Neurol Neurosurg Psychiatry 1951 ; 14: 216-21.

9 Feigin I, Wolf A. A disease in infants resembling chronic Wernicke's encephalopathy. J Pediatr 1954 ; 45: 243-63.

10 Clayton B E, Dobbs R H, Patrick A D. Leigh's subacute necrotising encephalopathy, a clinical and biochemical study with special reference to therapy with lipoate. Arch Dis Child 1967; 42: 467-78.

11 Hommes F A, Polman R A, Reerink J D. Leigh's encephalomyelopathy: an inborn error of gluconeogenesis. Arch Dis Child 1968; 43: 423-6.

12 Greenhouse A H, Schmeck S A. Subacute necrotizing encephalomyelopathy: a reappraisal of the thiamine deficiency hypothesis. Neurology (Minneap) 1968; 18: 1-8. 
13 Pincus J H, Itokawa Y, Cooper J R. Enzyme inhibiting factor in subacute necrotizing encephalomyelopathy. Neurology (Minneap) 1969; 19: 841-5.

14 Pincus J H, Solitaire G B, Itokawa Y, Hashitani Y, Cooper J R. Thiamine, thiamine triphosphate, and nervous system lesions in subacute necrotizing encephalomyelopathy (abstract). Neurology (Minneap) 1971; 21 : 444.

15 Reed M A. Letter: Leigh's disease: a family study. Lancet 1976; i: 1237.

16 Vo-Khactu K P, Clayburgh R H, Sandstead H H. An improved NADH-dependent transketolase assay for assessing thiamine nutriture. J Lab Clin Med 1974; 83: 983-9.

17 Brin M. Erythrocyte transketolase in early thiamine deficiency. Ann NY Acad Sci 1962; 98: 528-41.

18 Brin M, Vincent W, Watson J. Human thiamine deficiency and erythrocyte transketolase (abstract). Fed Proc 1962; 21: 468 .

19 Bamji M S. Transketolase activity and urinary excretion of thiamine in the assessment of thiamine nutrition status in Indians. Am J Clin Nutr 1970; 23: 52-8.

20 Basu T K, Dickerson J W T, Raven R W, Williams D C. The thiamine status of patients with cancer as determined by the red cell transketolase activity. Int J Vitam Nutr Res 1974 ; 44: 53-8.

21 Dirige O V, Jacob M, Ostergard N, Hunt I. Apoenzyme activities of erythrocyte transketolase, glutathione reductase, and glutamic-pyruvic transaminase during pregnancy. Am J Clin Nutr 1978; 31 : 202-5.

22 Gontzea I, Gorce $a$ V, Popescu F. Biochemical assessment of thiamine status in patients with neurosis. Nutr Metab 1975; 19: 153-7.
${ }^{23}$ Kjosen B, Seim S H. The transketolase assay of thiamine in some diseases. Am J Clin Nutr 1977; 30: 1591-6.

24 Grover W D, Auerbach V H, Patel M S. Biochemical studies and therapy in subacute necrotizing encephalomyelopathy (Leigh's syndrome). J Pediatr 1972; 81: 39-44.

25 Blass J P, Avigan J, Uhlendorf B W. A defect in pyruvate decarboxylase in a child with intermittent movement disorder. J Clin Invest 1970; 49: 423-32.

26 Farmer T W, Veath L, Miller A L, O'Brien J S, Rosenberg R M. Pyruvate decarboxylase deficiency in a patient with subacute necrotizing encephalomyelopathy (abstract). Neurology (Minneap) 1973; 23: 429.

27 Itokawa Y, Cooper J R. Ion movements and thiamine in nervous tissue. Intact nerve preparations. Biochem Pharmacol 1970; 19: 985-92.

28 Eichenbaum J W, Cooper J R. Restoration by thiamine of the action potential in ultraviolet irradiated nerve. Brain Res 1971; 32: 258-60.

${ }^{29}$ Waldenlind L. Studies on thiamine and neuromuscular transmission. Acta Physiol Scand (Suppl) 1978; No 459.

Correspondence to Professor H McIlwain, Department of Biochemistry, St Thomas's Hospital Medical School, Lambeth Palace Road, London SE1 7EH.

Received 5 June 1979 